\title{
STRUKTUR KEPEMILIKAN, KEBIJAKAN HUTANG DAN NILAI PERUSAHAAN : KEBIJAKAN DIVIDEN SEBAGAI VARIABEL MODERATING
}

\author{
Eka Mira Rismayanti ${ }^{1 *}$, Yusralaini Yusralaini ${ }^{2}$, Devi Safitri ${ }^{3}$ \\ ${ }^{123}$ Program Studi Akuntansi, Fakultas Ekonomi dan Bisni, Universitas Riau, Pekanbaru \\ *Email: ekamira08@gmail.com
}

\begin{tabular}{l}
\hline Keywords \\
\hline Debt Policy \\
Dividend Policy \\
Firm Value \\
Institutional Ownership \\
Managerial Ownership \\
\hline Article information \\
\hline Received: \\
2020-01-02 \\
Accepted: \\
2020-02-14 \\
Available Online: \\
2020-02-25
\end{tabular}

\begin{abstract}
The purpose of this research were to analyze the effect of managerial ownership, institutional ownership and debt policy of the fims value with dividend policy as moderation. Population on this research is all companies listed in IDX 2015-2017. This research sample selected by using the purposive sampling method, there are 228 sample. The analysis method of this research is multiple regression analysis and moderated regression analysis while hypothesis tested by using SPSS 25. The result of this research shows that: managerial ownership has negative effect on firm value. Institutional ownership has an effect on firm value. Debt policy has no effect on firm value. Dividend policy is able to moderated the relationship between managerial ownership and firm value. Dividend policy is able to moderated the relationship between institutional ownership and firm value. Dividend policy is not able to moderated the relationship between debt policy and firm value.
\end{abstract}

\section{PENDAHULUAN}

Nilai perusahaan merupakan hal sangat penting yang harus semestinya diperhatikan oleh perusahaan, dikarenakan nilai suatu perusahaan yang tinggi akan diikuti dengan tingginya kemakmuran pemegang saham (Brigham dan Houston, 2010). Harga saham merupakan cerminan nilai perusahaan. Nilai perusahaan didefinisikan sebagai harga yang bersedia dibayar oleh investor jika suatu perusahaan hendak dijual (Sartono, 2010). Memaksimalkan nilai perusahaan berarti memaksimalkan kemakmuran pemegang saham yang terima saat menjual aset persahaan sesuai dengan harga saham (Martono dan Harjitno, 2010). Harga saham yang tinggi, mencerminkan nilai perusahaan yang tinggi, begitu pula sebaliknya. Naik dan turunnya nilai perusahaan menjadi fenomena yang menarik untuk diteliti.

Fenomena mengenai nilai perusahaan yang dilansir dalam News Data Financial Tool Kontan, dimana dalam artikel itu disebutkan salah satu perusahaan maskapai penerbangan yaitu: PT Garuda Indonesia (GIAA) tengah menghadapi turbulensi. Pasalnya semenjak tahun 2015 perusahaan ini terus-menerus mengalami penurunan saham dimana berdasarkan laporan 
tahunan yang telah diterbitkan dapat dilihat bahwa pada tahun 2014 harga penutupan saham mencapai Rp 555 per lembar sahamnya. Sedangkan ditahun 2015 harga penutupan saham GIAA hanya Rp 309 per lembar sahamnya. Meskipun pada tahun 2016 saham GIAA mengalami kenaikan dari tahun sebelumnya, yaitu mencapai angka Rp 338 per lembar sahamnya, namun pada berikutnya perusahaan ini kembali mengalami penurunan harga saham dengan angka Rp 300 per lembar sahamnya. Penurunan harga saham perusahaan yang bergerak dibidang penerbangan ini dikhawatirkan mempengaruhi nilai perusahaan tersebut dimata para investor.

Naik dan turunnya nilai perusahaan ini berhubungan dengan struktur kepemilikan dan struktur pendanaan dalam perusahaan. Peningkatan nilai perusahaan akan tercapai jika ada kerja sama yang baik antara manajemen perusahaan dan pemegang saham. Pihak manajemen sebagai penerima amanah dari pihak pemegang saham seharusnya dapat menentukan kebijakan yang dapat meningkatkan nilai perusahaan. Kepemilikan institusional memiliki peran yang sangat penting dalam meminimalisir konflik keagenan yang terjadi antara manajer dan pemegang saham. Kepemilikan institusional dianggap dapat meningkatkan kualitas dan kuantitas pengawasan manajerial. Pengawasan manajer dalam menjalankan perusahaan untuk memaksimalkan kemakmuran pemegang saham.

Faktor-faktor yang diduga mempengaruhi nilai perusahaan, salah satunya adalah kepemilikan manajerial. Kepemilikan manajerial adalah pemegang saham oleh manajemen yang secara aktif berpartisipasi dalam pengambilan keputusan perusahaan, misalnya direktur dan komisaris (Pracihara, 2016). Hal ini diharapkan agar pihak manajemen dapat melakukan berbagai cara untuk meningkatkan nilai perusahaannya dan juga setiap keputusan yang diambil oleh pihak manajemen akan dirasakan secara langsung oleh pihak manajemen tersebut. Semakin besar proporsi kepemilikan manajerial pada perusahaan dapat menyatukan kepentingan antara manajer dengan pemegang saham, oleh karena itu diharapkan dapat meningkatkan nilai dan kinerja perusahaan (Jensen, 1986).

Hasil penelitian Anita dan Yulianto (2016) dan Sofyaningsih dan Hardiningsih (2011) menyatakan bahwa kepemilikan manajerial berpengaruh terhadap nilai perusahaan, dimana peningkatan kepemilikan manajemen dapat meningkatkan kemampuan perusahaan untuk menambah nilai perusahaan. Sedangkan hasil penelitian yang dilakukan oleh Tambalean et al. (2018) dan Warapsari dan Suaryana (2016) menyatakan bahwa kepemilikan manajerial tidak berpengaruh terhadap nilai perusahaan. Hal ini dikarenakan jumlah saham yang dimiliki oleh pihak manajemen pada perusahaan sektor industri barang konsumsi relatif sangat rendah, sehingga pihak manajemen tidak mendapatkan keuntungan yang diharapkan. 
Kepemilikan institusional merupakan kepemilikan saham perusahaan oleh institusi, seperti bank, perusahaan asuransi, perusahaan investasi dan institusi lainnya (Kusumaningrum dan Rahardjo, 2013). Peran pihak institusional dalam perusahaan adalah untuk mencegah tindakan oportunistik yang mungkin dilakukan oleh pihak manajemen. Kepemilikan institusional bertindak sebagai agen pengawasan yang secara optimal mengendalikan perilaku manajemen ketika memainkan peran dalam manajemen perusahaan (Sugiarto, 2011). Prinsip utama dari agency theory adalah adanya hubungan kerja antara pihak pemegang saham dengan pihak manajer dalam bentuk kontrak kerja sama. Adanya masalah keagenan disebabkan oleh perbedaan pendapat antara principle dan agent. Menurut Jensen dan Meckling (1976) hubungan keagenan merupakan hubungan dimana pemegang saham mempercayakan pengelolaan perusahaannya oleh pihak manajer. Manajer diamanahkan dalam mengelola perusahaan untuk meningkatkan kemakmuran pemegang saham, sebagai imbalannya pihak manajer akan diberikan imbalan atau kompensasi lainnya. Kemudian pihak institusi sebagai agen pengawasan yang akan mengawasi kinerja dari pihak manajer. Pengawasan ini dilakukan untuk mencegah perilaku oportunistik yang dilakukan oleh pihak manajer. Semakin tinggi kepemilikan saham oleh pihak institusi maka semakin besar usaha monitoring yang dilakukan. Kepemilikan saham institusional di Indonesia cukup besar sehingga keputusan para pemegang saham institusi mempengaruhi nilai perusahaan.

Hasil penelitian Zahro (2018) dan Damayanti dan Suartana (2014) menyimpulkan bahwa kepemilikan institusional berpengaruh terhadap nilai perusahan. Hal ini sejalan dengan teori keagenan yang memberikan penjelasan bahwa kepemilikan intitusional dapat mengurangi agency cost sehingga mampu meningkatkan nilai perusahaan. Sedangkan hasil penelitian Tambalean et al. (2018) dan Aditya dan Supriyono (2015) membuktikan bahwa kepemilikan institusional tidak berpengaruh terhadap nilai perusahaan. Hal ini disebabkan oleh fungsi pengawasan yang diemban oleh kepemilikan institusional tidak memiliki pengaruh yang signifikan dalam mengawasi kinerja manajer. Kurangnya keterlibatan kepemilikan saham institusi dalam pengambilan keputusan manajer juga mengakibatkan kepemilikan institusional tidak berdampak signifikan terhadap nilai perusahaan.

Kebijakan hutang adalah keputusan yang sangat penting bagi perusahaan. Kebijakan hutang merupakan bagian dari kebijakan pendanaan perusahaan. Kebijakan hutang adalah kebijakan yang diambil oleh eksekutif untuk memperoleh sumber keuangan perusahaan untuk kegiatan operasional perusahaan (Bambang, 2011). Kebijakan hutang dapat digunakan untuk menciptakan nilai perusahaan yang diinginkan. Penggunaan hutang harus dikelola dengan baik, karena penggunaan hutang merupakan hal yang sensitif bagi sebuah perusahaan 
terhadap naik turunnya nilai perusahaan. Semakin tinggi proporsi hutang yang ditetapkan sebuah perusahaan pada tingkat tertentu maka semakin tinggi nilai perusahaannya. Namun, apabila tingkat hutang melebihi proporsi hutang yang ditetapkan oleh perusahaan maka yang terjadi adalah penurunan nilai perusahaan (Pertiwi et al., 2016). Dalam trade off teori berasumsi bahwa dengan adanya manfaat pajak akibat penggunaan hutang, sehingga perusahaan akan menggunakan hutang pada tingkat tertentu untuk memaksimalkan nilai perusahaan. Ketika penggunaan hutang sudah melebihi batas optimal, maka dapat menyebabkan biaya kebangkrutan dan menurunkan nilai perusahaan.

Hasil penelitian Pratiwi dan Mertha (2017) dan Septriani (2017) menyatakan bahwa kebijakan hutang berpengaruh terhadap nilai perusahaan. Hal ini berkaitan dengan trade off teori, dimana peningkatan hutang memiliki hubungan yang positif dengan nilai perusahaan, dengan asumsi titik target struktur modal optimal belum tercapai. Sejauh manfaat yang diperoleh lebih besar dari biaya yang ditimbulkan akibat penggunaan hutang dibandingkan modal sendiri, maka nilai perusahaan meningkat. Sedangkan hasil penelitian Suta et al. (2016) menyimpulkan bahwa kebijakan hutang tidak berpengaruh terhadap nilai perusahaan. Hasil penelitian ini sejalan dengan teori struktur modal yang menjelaskan secara eksplisit mengakui tidak adanya hubungan antara pendanaan dan investasi. Artinya, baik menggunakan hutang atau tidak, pendanaan investasi perusahaan tidak akan memberikan perubahan pada nilai perusahaan (Normayanti, 2017).

Penelitian ini merupakan pengembangan penelitian dari Budianto dan Payamta (2014). Penelitian ini menambah variabel independen kepemilikan institusional. Penelitian ini menggunakan variabel moderasi kebijakan dividen. Kebijakan deviden menyangkut masalah penggunaan laba yang menjadi hak para pemegang saham. Pada dasarnya, laba tersebut dapat dibagikan sebagai dividen atau ditahan untuk diinvestasikan kembali (Husnan, 2010). Osman dan Mohammed (2010) mengemukakan bahwa pembayaran dividen berkaitan dengan teori sinyal. Pembayaran dividen yang meningkat dianggap sebagai sinyal yang baik bagi kondisi perusahaan serta menunjukkan prospek profitabilitas yang tinggi di masa depan. Hal ini berdampak pada peningkatan harga saham, sehingga perusahaan dapat membagikan dividen, dan menurunnya harga saham ketika dividen yang dibayarkan menurun. Dengan demikian, pembayaran dividen mempengaruhi nilai perusahaan, dan kebijakan dividen yang optimal dapat menciptakan keseimbangan antara dividen saat ini dan pertumbuhan masa depan (Brigham dan Houston, 2011). 


\section{PENGEMBANGAN HIPOTESIS}

\section{Pengaruh Kepemilikan Manajerial terhadap Nilai Perusahaan}

Kepemilikan manajerial adalah kepemilikan saham perusahaan oleh manajer atau dengan kata lain manajer tersebut sekaligus sebagai pemegang saham (Christiawan dan Tarigan, 2007). Nilai perusahaan merupakan harga pasar dari saham perusahaan karena harga pasar saham dianggap sebagai cerminan dari nilai aset perusahaan yang sesungguhnya. Dalam teori agensi dapat dijelaskan dengan hubungan antara manajemen dengan pemilik, manajemen sebagai agen secara moral bertanggungjawab untuk mengoptimalkan keuntungan para pemilik dan manajemen mendapatkan komisi sebagai imbalannya. Manajer yang sama-sama pemegang saham akan berusaha meningkatkan nilai perusahaan sehingga nilai kekayaan mereka sebagai pemegang saham juga akan meningkat. Hasil penelitian oleh Pratiwi et al. (2016) menyatakan bahwa kepemilikan manajerial berpengaruh positif terhadap nilai perusahaan. Hal ini dikarenakan adaya kepemilikan manajerial akan mensejajarkan kepentingan manajemen dan pemegang saham. Kepemilikan dapat membantu penyatuan kepentingan antara pemegang saham dan manajemen. Sehingga semakin meningkat proporsi kepemilikan saham manajerial maka semakin baik kinerjanya yang akan berdampak pada peningkatan nilai perusahaan.

Berbeda dengan hasil penelitian yang dilakukan oleh Dewi and Sanica (2017) yang menyatakan bahwa kepemilikan manajerial berpengaruh negatif terhadap nilai perusahaan. Hal ini dikarenakan kepemilikan manajerial pada sektor manufaktur masih sangat rendah. Rendahnya saham yang dimiliki oleh manajemen mengakibatkan pihak manajemen belum merasa ikut memiliki perusahaan karena tidak semua keuntungan dapat dinikmati oleh manajemen yang menyebabkan pihak manajemen termotivasi untuk memaksimalkan utilitasnya sehingga merugikan pemegang saham. Selain itu dengan rendahnya kepemilikan saham oleh manajemen membuat kinerja manajemen cenderung rendah sehingga dapat menurunkan nilai perusahaan.

\section{$\mathrm{H}_{1}$ : Kepemilikan manajerial berpengaruh terhadap nilai perusahaan.}

\section{Pengaruh Kepemilikan Institusional terhadap Nilai Perusahaan}

Kepemilikan Institusional merupakan persentase saham perusahaan yang dimiliki oleh institusi atau lembaga (Nuraina, 2012:116). Kepemilikan institusional merupakan satu alat yang dapat digunakan untuk mengurangi agency conflict. Kepemilikan institusional memiliki kemampuan untuk mengelola manajemen melalui proses pemantauan yang efektif. Nilai perusahaan merupakan harga pasar dari saham perusahaan karena harga pasar saham 
dianggap sebagai cerminan dari nilai aset perusahaan yang sesungguhnya. Kepemilikan oleh institusi berperan penting dalam hal pengawasan yang lebih optimal kepada manajemen sehingga mampu menekan perilaku oportunistik yang mungkin dilakukan manajer dan dapat memantau pengambilan keputusan perusahaan. Pengawasan tersebut mendorong peningkatan kinerja manajemen dan berdampak positif pada nilai perusahaan.

Hasil penelitian menurut Pratiwi et al. (2016) dan Lestari (2017) yang menyatakan bahwa kepemilikan institusional berpengaruh positif terhadap nilai perusahaan. Kepemilikan institusional dapat meningkatkan nilai perusahaan apabila institusi tersebut dapat menjadi alat monitoring yang efektif yang mampu mengubah struktur pengelolaan perusahaan dan mampu meningkatkan kemakmuran pemegang saham. Sedangkan hasil penelitian menurut Rahma (2014) menyatakan bahwa kepemilikan institusional berpengaruh negatif terhadap nilai perusahaan. Hal ini menunjukkan bahwa semakin besar jumlah kepemilikan institusional akan menurunkan price book value. Konsisten dengan the strategic alignment hypothesis bahwa investor institusi dengan kepentingan mayoritas lebih cenderung untuk memihak dan bekerja dengan manajemen untuk mengutamakan kepentingan pribadi mereka.

\section{$\mathrm{H}_{2}$ : Kepemilikan institusional berpengaruh terhadap nilai perusahaan.}

\section{Pengaruh Kebijakan Hutang terhadap Nilai Perusahaan}

Kebijakan hutang merupakan kebijakan perusahaan tentang seberapa jauh sebuah perusahaan menggunakan pendanaan hutang (Mardiyati et al., 2012). Dalam trade off teori berasumsi bahwa dengan adanya manfaat pajak akibat penggunaan hutang, sehingga perusahaan akan menggunakan hutang pada tingkat tertentu untuk memaksimalkan nilai perusahaan. Ketika penggunaan hutang sudah melebihi batas optimal penggunaan hutang, maka penggunaan hutang akan menyebabkan biaya kebangkrutan dan akan menurunkan nilai perusahaan.

Nilai perusahaan merupakan harga pasar dari saham perusahaan karena harga pasar saham dianggap sebagai cerminan dari nilai aset perusahaan yang sesungguhnya. Adanya penggunaan hutang juga dapat mempengaruhi harga saham perusahaan. Hutang merupakan sumber pendanaan eksternal perusahaan untuk menjalankan kegiatan operasionalnya. Semakin tinggi proporsi hutang yang ditetapkan perusahaan pada tingkat tertentu, maka semakin tinggi nilai perusahaan. Jika tingkat hutang melebihi proporsi yang ditetapkan oleh perusahaan, maka nilai perusahaan akan turun, karena manfaat yang diperoleh dari penggunaan hutang relative kecil daripada biaya yang ditimbulkan. 
Penelitian Pratiwi dan Mertha (2017) dan Sukirni (2012) menyimpulkan bahwa kebijakan hutang berpengaruh terhadap nilai perusahaan. Kebijakan perusahaan dengan menambah penggunaan hutang dibandingkan modal sendiri akan direspon positif oleh investor, yang akan meningkatkan nilai perusahaan. Penambahan hutang dapat memberikan sinyal positif, karena diartikan oleh investor sebagai kemampuan perusahaan untuk membayar kewajibannya di masa yang akan datang. Sedangkan hasil penelitian menurut (Ramadhan et al., 2018) menyatakan bahwa kebijakan hutang berpengaruh negatif terhadap nilai perusahaan. Hal ini dikarenakan tingginya hutang yang digunakan oleh perusahaan maka resiko yang akan dihadapi oleh perusahaan juga akan tinggi. Hal ini menyebabkan penurunan nilai perusahaan dikarenakan tingkat hutang yang tinggi akan mempengaruh nilai perusahaan.

\section{$\mathrm{H}_{3}$ : Kebijakan hutang berpengaruh terhadap nilai perusahaan.}

\section{Pengaruh Kepemilikan Manajerial terhadap Nilai Perusahaan dengan Kebijakan Dividen sebagai Variabel Moderating}

Dividen merupakan salah satu faktor yang diduga berpengaruh terhadap nilai perusahaan (Olweny, 2012). Itturiaga dan Crisostomo (2010) menjelaskan bahwa keputusan tentang dividen mengundang perdebatan dikalangan peneliti keuangan. (Abdullah et al., 2012) menyatakan bahwa kebijakan dividen merupakan salah satu isu kontroversi dibidang keuangan yang menarik untuk diteliti.

Sulong dan Nor (2010) menyatakan bahwa perusahaan diharapkan membayar dividen pada perusahaan yang memiliki komisaris independen yang lebih besar. Dividen merupakan bagian dari laba perusahaan yang dibagikan dalam rangka peningkatan kesejahteraan pemegang saham. Semakin sejahtera pemegang saham akan semakin tinggi nilai perusahaan. Atmaja (2009) menyatakan bahwa dividen dapat digunakan untuk mengendalikan pemegang saham perusahaan pada perusahaan dengan tipe kepemilikan terkonsentrasi. Hasil penelitian yang dilakukan oleh Budianto dan Payamta (2014) menyatakan bahwa kebijakan dividen memoderasi pengaruh kepemilikan manajerial terhadap nilai perusahaan. Dividen dapat meningkatkan komunikasi dan koordinasi dalam perusahaan sehingga dapat mengurangi biaya keagenan dan meningkatkan nilai perusahaan. Semakin banyak dividen yang dibagikan kepada pemegang saham, semakin baik kinerja perusahaan. Pada akhirnya, penilaian perusahaan akan menghasilkan harga saham yang lebih baik.

\section{$\mathrm{H}_{4}$ : Kebijakan dividen memoderasi hubungan antara kepemilikan manajerial terhadap nilai perusahaan.}


Pengaruh Kepemilikan Institusional terhadap Nilai Perusahaan dengan Kebijakan Dividen sebagai Variabel Moderating

Dalam teori sinyal dividen dinyatakan bahwa pengumuman pembayaran dividen mengandung informasi yang dapat menimbulkan reaksi pasar. Investor menilai perubahan dividen sebagai sinyal ramalan laba oleh manajemen. Peningkatan pembayaran dividen seringkali dianggap sebagai sinyal positif prospek perusahaan yang baik dan mengakibatkan reaksi positif harga saham. Dalam teori sinyal kebijakan dividen oleh Gordon dan Lintner menyatakan semakin tinggi dividen yang dibayarkan maka akan berdampak positif ada nilai perusahaan yang berarti juga akan meningkatkan kesejahteraan pemegang saham.

\section{$\mathrm{H}_{5}$ : Kebijakan dividen memoderasi hubungan antara kepemilikan institusional terhadap nilai perusahaan.}

\section{Pengaruh Kebijakan Hutang terhadap Nilai Perusahaan dengan Kebijakan Dividen sebagai Variabel Moderating}

Kebijakan dividen adalah kebijakan yang terkait dengan pembayaran dividen oleh perusahaan. Dividen merupakan laba yang akan dibagi kepada pemegang saham dengan proporsi tertentu dan sebagian laba tersebut akan ditahan sebagai investasi. Penggunaan hutang akan menimbulkan resiko bagi perusahaan apabila tidak dimanfaatkan dikelola secara optimal. Namun apabila perusahaan mampu menghasilkan laba melalui penggunaan hutang berarti penggunaan hutang bermanfaat bagi perusahaan. Perusahaan yang mampu mengelola utang dengan baik dan membayarkan dividen dengan rutin akan meningkatkan nilai perusahaan melalui peningkatan harga saham. Hasil penelitian yang dilakukan oleh Febria (2019) yang menyatakan bahwa kebijakan dividen memoderasi hubungan kebijakan hutang terhadap nilai perusahaan. Kebijakan dividen merupakan bagian dari keputusan pendanaan karena berkaitan dengan pendanaan internal berupa laba ditahan. Semakin besar laba yang diperoleh perusahaan, semakin besar pula kesempatan perusahaan untuk membayarkan dividen. Semakin besar laba bersih yang dibayarkan sebagai dividen maka semakin kecil laba ditahan, dan sebaliknya. Hal ini akan berdampak pada penggunaan sumber dana esternal seperti hutang.

\footnotetext{
$\mathrm{H}_{6}$ : Kebijakan dividen memoderasi hubungan antara kebijakan hutang terhadap nilai perusahaan.
} 


\section{METODE PENELITIAN}

Objek dari penelitian ini adalah seluruh perusahaan yang terdaftar di Bursa Efek Indonesia (BEI) periode 2015-2017. Data yang digunakan yaitu jenis data sekunder yang merupakan data yang diperoleh dari website IDX. Populasi dari penelitian ini adalah seluruh perusahaan yang terdaftar di BEI tahun 2015-2017. Penelitian ini menggunakan teknik purposive sampling dengan kriteria sebagai berikut:

1. Seluruh perusahaan yang terdaftar di BEI tahun 2015-2017 kecuali bank dan lembaga keuangan.

2. Perusahaan yang delisting.

3. Perusahaan yang membagikan dividen selama tahun 2015-2017.

4. Perusahaan yang memiliki kepemilikan manajerial.

5. Perusahaan yang memiliki laporan tahunan yang lengkap.

6. Laporan tahunan disajikan dalam mata uang rupiah.

\section{Definisi Operasional dan Pengukuran Variabel}

Nilai perusahaan diartikan sebagai harga yang bersedia dibayar oleh investor seandainya suatu perusahaan akan dijual (Sartono, 2010). Nilai perusahaan diukur dengan menggunakan rasio PBV (Price Book Value). PBV salah satu indikator paling penting untuk melihat apakah suatu saham itu mahal atau tidak. Nilai buku adalah nilai dari ekuitas dibagi jumlah saham yang ada.

$$
\text { Price to Book Value }=\quad \frac{\text { harga perlembarsaham }}{\text { nilaibuku perlembar saham }}(\text { Budianto dan Payamta, 2014) }
$$

Kepemilikan manajerial adalah kepemilikan saham perusahaan oleh manajer. Kepemilikan manajerial diukur dengan persentase saham yang dimiliki oleh manajemen dibagi dengan jumlah saham yang beredar (Budianto dan Payamta, 2014).

$$
\text { Kepemilikan Manajerial }=\quad \frac{j \text { uml ah saham yang dim liki manajer }}{j u m l \text { ah saham yang beredar }}((\text { Hidayah, 2015). }
$$

Kepemilikan institusional merupakan proporsi saham perusahaan yang dimiliki oleh institusi atau lembaga, seperti bank, perusahaan asuransi, perusahaan investasi atau institusi lain (Kusumaningrum dan Rahardjo, 2013). Kepemilikan institusional diukur dengan menggunakan indikator persentase jumlah saham yang dimiliki saham institusional terhadap jumlah total saham suatu perusahaan (Wulandari, 2016).

$$
\mathrm{KI}=\quad \frac{j \text { uml ah saham yang dim liki institus1 }}{j \text { uml ah saham yang beredar }} \text { (Wulandari, 2016) }
$$

Kebijakan hutang merupak kebijakan yang diambil perusahaan untuk melakukan 
pembiayaan melalui hutang. Kebijakan hutang pada penelitian ini diukur dengan menggunakan Debt to Asset Ratio (DAR), yaitu total hutang yang dibagi dengan total aset (Kasmir, 2012:156).

Kebijakan dividen merupakan keputusan yang diambil perusahaan apakah laba yang diperoleh akan dibagikan kepada pemegang saham atau ditahan dalam bentuk laba ditahan. Kebijakan dividen diukur dengan Dividend Payout Ratio (DPR), yaitu dividen per lembar saham dibagi dengan laba bersih per lembar saham (Putri, 2017).

\section{Teknik Analisis Data}

Analisis yang digunakan dalam penelitian ini merupakan analisis regresi linier berganda dan MRA (Moderated Regression Analysis). Adapun model persamaan regresi linier berganda dalam penelitian ini adalah sebagai berikut:

$Y=\alpha+\beta_{1} X_{1}+\beta_{2} X_{2}+\beta_{3} X_{3}+\varepsilon$

Kemudian untuk model persamaan MRA dalam penelitian ini adalah sebagai berikut:

$$
\begin{aligned}
& Y=\alpha+\beta_{1} X_{1}+\beta_{2} Z+\beta_{3} X_{1} Z+\varepsilon \\
& Y=\alpha+\beta_{1} X_{2}+\beta_{2} Z+\beta_{3} X_{2 . Z}+\varepsilon \\
& Y=\alpha+\beta_{1} X_{3}+\beta_{2} Z+\beta_{3} X_{3} . Z+\varepsilon
\end{aligned}
$$

Keterangan:

$\alpha \quad=$ Konstanta

$X_{1}=$ Kepemilikan Manajerial

$X_{2}=$ Kepemilikan institusional

$X_{3} \quad=$ Kebijakan hutang

$\mathrm{Z} \quad=$ Kebijakan Dividen

$\varepsilon \quad=$ eror

Jika nilai $t_{\text {hitung }}$ lebih besar dari nilai $t_{\text {tabel }}$ maka terdapat pengaruh, namun jika $t_{\text {hitung }}$ lebih kecil dari $t_{\text {tabel }}$ maka tidak terjadi pengaruh (Ghozali, 2016). Jika nilai signifikan lebih kecil dari 0,05 dan koefisien regresi memiliki arah yang sama dengan hipotesis, maka hal ini menunjukkan bahwa variabel independen berpengaruh terhadap variabel dependen (Ghozali, 2016).

\section{HASIL PENELITIAN DAN PEMBAHASAN}

Berdasarkan hasil seleksi sampel dengan teknik purposive sampling didapatkan sejumlah 228 data dari 76 perusahaan. Data yang digunakan berupa laporan keuangan perusahaan dan menggunakan mata uang rupiah. Hasil analisis diperoleh dengan analisis 
regresi linier berganda dan moderated regression analysis dengan software SPSS 25.

Tabel 1

Hasil Uji Analisis Regresi Linier Berganda

\begin{tabular}{|c|c|c|c|c|c|c|}
\hline \multirow[b]{2}{*}{ Model } & & \multicolumn{2}{|c|}{ Unstandardized Coefficients } & \multirow{2}{*}{$\begin{array}{c}\begin{array}{c}\text { Standardized } \\
\text { Coefficients }\end{array} \\
\text { Beta }\end{array}$} & \multirow[b]{2}{*}{$\mathbf{T}$} & \multirow[b]{2}{*}{ Sig. } \\
\hline & & $\mathbf{B}$ & Std. Error & & & \\
\hline \multirow[t]{4}{*}{1} & (Constant) & 6,700 & 1,940 & & 3,453 & 0,001 \\
\hline & Kepemilikan Manajerial & $-9,459$ & 4,099 & $-0,169$ & $-2,307$ & 0,022 \\
\hline & Kepemilikan Institusional & 8,704 & 2,382 & 0,262 & 3,654 & 0,000 \\
\hline & Kebijakan Hutang & 0,259 & 0,398 & 0,133 & 0,649 & 0,517 \\
\hline
\end{tabular}

Sumber: Pengolahan data dengan SPSS

Tabel 2

Hasil Uji MRA Hipotesis Keempat

\begin{tabular}{|c|c|c|c|c|c|c|}
\hline \multirow[b]{2}{*}{ Model } & & \multicolumn{2}{|c|}{ Unstandardized Coefficients } & \multirow{2}{*}{$\begin{array}{c}\begin{array}{c}\text { Standardized } \\
\text { Coefficients }\end{array} \\
\text { Beta } \\
\end{array}$} & \multirow[b]{2}{*}{ 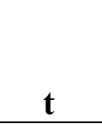 } & \multirow[b]{2}{*}{ Sig. } \\
\hline & & B & Std. Error & & & \\
\hline \multirow[t]{4}{*}{1} & (Constant) & 2,723 & 0,596 & & 4,569 & 0,000 \\
\hline & Kepemilikan Manajerial & 9,960 & 4,245 & 0,175 & 2,150 & 0,033 \\
\hline & Kebijakan Dividen & 0,011 & 0,010 & 0,128 & 1,088 & 0,278 \\
\hline & Moderasi 1 & 1,110 & 0,499 & 1,328 & 2,225 & 0,028 \\
\hline
\end{tabular}

Sumber: Pengolahan data dengan SPSS

Tabel 3

Hasil Uji MRA Hipotesis Kelima

\begin{tabular}{|c|c|c|c|c|c|c|}
\hline \multirow{2}{*}{\multicolumn{2}{|c|}{ Model }} & \multicolumn{2}{|c|}{$\begin{array}{c}\text { Unstandardized } \\
\text { Coefficients }\end{array}$} & \multirow{2}{*}{$\begin{array}{c}\begin{array}{c}\text { Standardized } \\
\text { Coefficients }\end{array} \\
\text { Beta } \\
\end{array}$} & \multirow[t]{2}{*}{$\mathbf{t}$} & \multirow[t]{2}{*}{ Sig. } \\
\hline & & B & Std. Error & & & \\
\hline \multirow[t]{4}{*}{1} & (Constant) & 5,716 & 1,544 & & 3,702 & 0,000 \\
\hline & Kepemilikan Institusional & 6,048 & 2,174 & 0,182 & 2,782 & 0,006 \\
\hline & Kebijakan Dividen & 0,219 & 0,091 & 0,770 & 2,402 & 0,017 \\
\hline & Moderasi 2 & 2,803 & 1,302 & 0,719 & 2,152 & 0,032 \\
\hline
\end{tabular}

Sumber: Pengolahan data dengan SPSS

Tabel 4

Hasil Uji MRA Hipotesis Keenam

\begin{tabular}{|c|c|c|c|c|c|c|}
\hline & \multirow[b]{2}{*}{ Model } & \multicolumn{2}{|c|}{ Unstandardized Coefficients } & \multirow{2}{*}{$\begin{array}{c}\text { Coefficients } \\
\text { Beta } \\
\end{array}$} & \multirow[b]{2}{*}{$\mathbf{t}$} & \multirow[b]{2}{*}{ Sig. } \\
\hline & & B & Std. Error & & & \\
\hline \multirow[t]{4}{*}{1} & (Constant) & 0,885 & 1,180 & & 0,750 & 0,001 \\
\hline & Kebijakan Hutang & 0,049 & 0,020 & 0,160 & 2,429 & 0,016 \\
\hline & Kebijakan Dividen & $-0,011$ & 0,014 & $-0,122$ & $-0,743$ & 0,458 \\
\hline & Moderasi 3 & 5,001 & 3,760 & 0,220 & 1,330 & 0,185 \\
\hline
\end{tabular}

Sumber: Pengolahan data dengan SPSS

\section{Pengaruh Kepemilikan Manajerial terhadap Nilai Perusahaan}

Kepemilikan manajerial dapat dilihat dari seberapa banyak saham yang dimiliki oleh manajemen. Proksi kepemilikan manajerial melalui perbandingan jumlah saham manajerial 
dan total saham yang beredar. Hasil pengujian persamaan regresi berganda pada Tabel 3 dapat dilihat bahwa variabel kepemilikan manajerial memiliki t hitung -2,307 dan $t$ tabel 1,972 yang menunjukkan bahwa thitung $>\mathrm{t}$ tabel $(-2,307>1,972)$. Menunjukkan bahwa kepemilikan manajerial mempunyai nilai sig 0,022. Nilai tersebut sesuai dengan standar signifikan yaitu lebih kecil dari 0,05. Berdasarkan hasil tersebut dapat disimpulkan bahwa hipotesis 1 diterima, yang berarti bahwa kepemilikan manajerial berpengaruh negatif terhadap nilai perusahaan.

Secara teoritis menyatakan, semakin tinggi kepemilikan manajerial suatu perusahaan maka manajer akan menyelaraskan kepentingannya sebagai manajer dan pemegang saham. Manajer akan berusaha sekeras mungkin atau menguasahakan segala sesuatu untuk meningkatkan nilai perusahaannya. Namun hasil penelitian ini menyatakan bahwa kepemilikan manajerial berpengaruh negatif terhadap nilai perusahaan. Hal ini dikarenakan persentase saham yang dimiliki oleh pihak manajer masih sangat kecil dalam perusahaan yang terdaftar di BEI, sehingga pihak manajer belum merasakan manfaat dari kepemilikan tersebut dan belum memiliki rasa tanggungjawab yang besar untuk perusahaan, sehingga pihak manajer lebih mengutamakan kepentingannya sendiri dan mengutamakan pendapatan yang tinggi dari pada kepentingannya sebagai pemegang saham untuk meningkatkan nilai perusahaan.

Hasil penelitian yang dilakukan oleh Sukirni (2012) yang menyatakan bahwa kepemilikan manajerial berpengaruh negatif terhadap nilai perusahaan. Hal ini dikarenakan belum banyak pihak manajemen yang memiliki saham perusahaan dengan jumlah yang signifikan. Jumlah kepemilikan manajerial yang rendah menyebabkan pihak manajemen lebih mementingkan kepentingannya sendiri daripada kepentingan perusahaan. Jumlah kepemilikan yang belum signifikan tersebut menyebabkan manajer lebih mementingkan tujuannya sebagai seorang manajer daripada sebagai pemegang saham.

Hasil penelitian ini sejalan dengan penelitian yang telah dilakukan oleh Rahma (2014), Bernandhi dan Muid (2014), Sukirni (2012) yang menyatakan bahwa kepemilikan manajerial berpengaruh negatif terhadap nilai perusahaan. Berbeda dengan hasil penelitian yang dilakukan oleh Pratiwi et al. (2016) menyatakan bahwa kepemilikan manajerial berpengaruh positif terhadap nilai perusahaan. Hal ini dikarenakan adaya kepemilikan manajerial akan mensejajarkan kepentingan manajemen dan pemegang saham. Kepemilikan dapat membantu penyatuan kepentingan antara pemegang saham dan manajemen. Sehingga semakin meningkat proporsi kepemilikan saham manajerial maka semakin baik kinerjanya yang akan berdampak pada peningkatan nilai perusahaan. 


\section{Pengaruh Kepemilikan Institusional terhadap Nilai Perusahaan}

Kepemilikan institusional dapat dilihat dari seberapa banyak saham yang dimiliki oleh institusi. Proksi kepemilikan institusional melalui perbandingan jumlah saham institusi dan total saham yang beredar. Hasil pengujian persamaan regresi berganda pada Tabel 3 dapat dilihat bahwa variabel kepemilikan institusional memiliki t hitung 3,654 dan t tabel 1,972 yang menunjukkan bahwa t hitung $>\mathrm{t}$ tabel $(3,654>1,972)$ dan juga menunjukkan bahwa kepemilikan institusional mempunyai nilai sig 0,000. Nilai tersebut sesuai dengan standar signifikan yaitu lebih kecil dari 0,05. Berdasarkan hasil tersebut dapat disimpulkan bahwa hipotesis 2 diterima, yang berarti bahwa kepemilikan institusional berpengaruh positif terhadap nilai perusahaan.

Berdasarkan hasil penelitian ini, dapat disimpulkan bawa kepemilikan institusional berpengaruh terhadap nilai perusahaan pada perusahaan yang terdaftar di BEI. Kepemilikan institusional mendorong pengawasan lebih optimal terhadap kinerja perusahaan. Hal ini berarti semakin besar persentase saham oleh pihak institusi maka akan menyebabkan usaha monitoring menjadi semakin efektif karena dapat mengendalikan perilaku oportunistik yang dilakukan pihak manajer. Usaha monitoring yang efektif mampu mengubah struktur pengelolaan perusahaan dan mampu meningkatkan kesejahteraan pemegang saham yang juga berarti meningkatkan nilai perusahaan.

Hasil penelitian menurut Pratiwi et al. (2016) dan Lestari (2017) yang menyatakan bahwa kepemilikan institusional berpengaruh positif terhadap nilai perusahaan. Kepemilikan institusional dapat meningkatkan nilai perusahaan apabila institusi tersebut dapat menjadi alat monitoring yang efektif yang mampu mengubah struktur pengelolaan perusahaan dan mampu meningkatkan kemakmuran pemegang saham. Hasil penelitian ini sejalan dengan penelitian yang telah dilakukan oleh Pratiwi et al. (2016), Lestari (2017) dan Damayanti and Suartana (2014) yang menyatakan bahwa kepemilikan institusional berpengaruh terhadap nilai perusahaan. Berbeda dengan hasil penelitian yang dilakukan oleh Aditya and Supriyono (2015) yang menyatakan bahwa kepemilikan institusional tidak berpengaruh terhadap nilai perusahaan. Hal ini dikarenakan bahwa besar atau kecilnya kepemilikan institusional atas perusahaan belum mampu mengontrol dan mengawasi tindakan oportunistik manajer dalam menjalankan perusahaan, dengan kata lain investor institusional tidak dapat mengoptimalkan fungsi control yang dimilikinya. 


\section{Pengaruh Kebijakan Hutang terhadap Nilai Perusahaan}

Kebijakan hutang dapat dilihat dari seberapa banyak hutang yang dimiliki perusahaan. Proksi kebijakan hutang melalui perbandingan jumlah hutang dan total aset perusahaan. Hasil pengujian persamaan regresi berganda pada Tabel 3 menunjukkan bahwa kebijakan hutang mempunyai nilai sig 0,517 . Nilai tersebut tidak sesuai dengan standar signifikan yaitu lebih besar dari 0,05. Berdasarkan hasil tersebut dapat disimpulkan bahwa hipotesis 3 ditolak, yang berarti bahwa kebijakan hutang tidak berpengaruh terhadap nilai perusahaan.

Dari hasil penelitian ini, dapat disimpulkan bahwa kebijakan hutang tidak berpengaruh terhadap nilai perusahaan. Data dalam penelitian ini menunjukkan bahwa perusahaan dengan tingkat hutang yang rendah tidak memiliki nilai perusahaan yang tinggi, begitu pula sebaliknya, perusahaan dengan tingkat hutang yang tinggi tidak memiliki nilai perusahaan yang rendah. Hal ini dapat disimpulkan bahwa tinggi atau rendahnya hutang suatu perusahaan tidak searah dengan naik atau turunnya nilai perusahaan. Hal inilah yang menyebabkan kebijakan hutang tidak berpengaruh terhadap nilai perusahaan.

Hasil penelitian yang dilakukan oleh Normayanti (2017) yang menyatakan bahwa kebijakan hutang tidak berpengaruh terhadap nilai perusahaan. Hal ini sesuai dengan teori yang dikemukakan oleh Miller dan Modigliani (dalam Normayanti, 2017) yang mengakui bahwa tidak adanya hubungan dari pendanaan dan investasi. Dalam arti bahwa menggunakan hutang atau tanpa hutang tidak berpengaruh terhadap perubahan nilai perusahaan karena pemegang saham lebih memperhatikan terkait bagaimana perusahaan menghasilkan laba. Penggunakan hutang yang berlebih akan memperbesar risiko perusahaan dalam menghasilkan laba dan menyebabkan keraguan pemegang saham terhadap kemampuan perusahaan dalam mengembalikan pinjamannya. Hal ini akan berimplikasi pada laba bersih yanag diperoleh perusahaan sehingga akan menurunkan nilai perusahaan.

Hasil penelitian ini sejalan dengan penelitian yang telah dilakukan oleh Ramadhan et al. (2018), Suta et al. (2016) yang menyatakan bahwa kebijakan hutang tidak berpengaruh terhadap nilai perusahaan. Berbeda dengan hasil penelitian menurut Pratiwi dan Mertha (2017) dan Septriani (2017) menyatakan bahwa kebijakan hutang berpengaruh terhadap nilai perusahaan. Kebijakan perusahaan dengan penggunaan hutang dibandingkan modal perusahaan akan mendapat respon positif oleh investor, yang akan meningkatkan nilai perusahaan. Penambahan hutang memberikan sinyal positif, karena diartikan oleh investor sebagai kemampuan perusahaan membayar kewajibannya di masa depan. 


\section{Pengaruh Kepemilikan Manajerial terhadap Nilai Perusahaan dengan Kebijakan Dividen sebagai Variabel Moderating}

Dari hasil pengujian MRA Tabel 4 dapat dilihat bahwa t hitung sebesar 2,225 dan $\mathrm{t}$ tabel sebesar 1,972 menunjukkan bahwa $t$ hitung $>\mathrm{t}$ tabel $(2,225>1,972)$. Nilai signifikansi sebesar 0,028 yang artinya lebih kecil dari tingkat signifikansi 0,05 $(0,028<0,05)$. Berdasarkan hasil penelitian ini, dapat disimpulkan bahwa kebijakan dividen mampu memoderasi pengaruh kepemilikan manajerial terhadap nilai perusahaan pada perusahaan yang terdaftar di BEI. Kebijakan dividen adalah kebijakan mengenai pembayaran dividen oleh perusahaan. Dividen merupakan laba yang akan dibagi kepada pemegang saham dengan proporsi tertentu sesuai dengan jumlah saham yang dimiliki. Kebijakan dividen merupakan variabel moderating yang memperlemah efek negatif kepemilikan manajerial terhadap nilai perusahaan.

Variabel kepemilikan manajerial yang pada analisis regresi berganda pada awalnya berpengaruh negatif menjadi berpengaruh positif setelah adanya variabel kebijakan dividen. Hal ini menunjukkan adanya kebijakan dividen yang dilakukan oleh perusahaan akan mengurangi efek negatif kepemilikan manajerial terhadap nilai perusahaan.

Itturiaga dan Crisostomo (2010) menyatakan teori sinyal dan teori arus kas bebas menjelaskan bahwa dividen mempengaruhi nilai perusahaan dengan mempertimbangkan ada atau tidak pertumbuhan dalam perusahaan. Perusahaan akan memberikan sinyal ketika ia membayarkan dividen. peningkatan pembayaran dividen diharapkan memberikan pengaruh yang positif terhadap nilai perusahaan. Sulong dan Nor (2010) menyatakan bahwa perusahaan diharapkan membayar dividen lebih tinggi pada perusahaan yang memiliki komisaris independen yang lebih besar. Dividen merupakan bagian dari laba perusahaan yang dibagikan dalam rangka peningkatan kesehateraan pemegang saham. Semakin sejahtera pemegang saham akan semakin tinggi nilai perusahaan. Perusahaan dengan dividen yang tinggi memiliki masalah keagenan yang lebih rendah dibandingkan dengan perusahaan yang membayarkan dividen rendah.

Hasil penelitian ini sejalan dengan penelitian yang telah dilakukan oleh Budianto dan Payamta (2014) yang menyatakan bahwa kebijakan dividen memoderasi hubungan antara kepemilikan manajerial terhadap nilai perusahaan. Kebijakan dividen berpengaruh positif terhadap nilai perusahaan. Pasar bereaksi negatif terhadap kepemilikan manajerial yang besar, namun reaksi tersebut akan menjadi berbeda jika perusahaan membayarkan dividen. Pasar bereaksi positif dengan adanya kebijakan dividen dan mengurangi dampaka negatif kepemilikan manajerial terhadap nilai perusahaan. Kebijakan dividen menjadi hal yang sangat 
penting yang berdampak positif terhadap nilai perusahaan. Semakin besar dividen yang dibayarkan perusahaan maka akan semakin besar pula nilai perusahaan.

\section{Pengaruh Kepemilikan Institusional terhadap Nilai Perusahaan dengan Kebijakan Dividen sebagai Variabel Moderating}

Dari hasil pengujian MRA Tabel 5 dapat dilihat bahwa $\mathrm{t}$ hitung sebesar 2,152 dan $\mathrm{t}$ tabel sebesar 1,972 menunjukkan bahwa $t$ hitung $>t$ tabel $(2,152>1,972)$. Nilai signifikansi sebesar 0,032 yang artinya lebih kecil dari tingkat signifikansi 0,05 $(0,032<0,05)$. Berdasarkan hasil penelitian ini, dapat disimpulkan bahwa kebijakan dividen mampu memoderasi pengaruh kepemilikan institusional terhadap nilai perusahaan pada perusahaan yang terdaftar di BEI. Dalam teori sinyal dividen dinyatakan bahwa pengumuman pembayaran dividen mengandung informasi yang dapat menimbulkan reaksi pasar. Investor menilai perubahan dividen sebagai sinyal ramalan laba oleh manajemen. Peningkatan pembayaran dividen seringkali dianggap sebagai sinyal positif prospek perusahaan yang baik dan mengakibatkan reaksi positif harga saham. Dalam teori kebijakan dividen oleh Gordon dan Lintner menyatakan semakin tinggi dividen yang dibayarkan kepada pemegang saham akan berdampak positif pada nilai perusahaan yang berarti juga semakin meningkatnya kesejahteraan pemegang saham.

\section{Pengaruh Kebijakan Hutang terhadap Nilai Perusahaan dengan Kebijakan Dividen sebagai Variabel Moderating}

Dari hasil pengujian MRA Tabel 6 dapat dilihat bahwa $\mathrm{t}$ hitung sebesar 1,330 dan $\mathrm{t}$ tabel sebesar 1,972 menunjukkan bahwa $\mathrm{t}$ hitung $<\mathrm{t}$ tabel $(2,152<1,972)$. Nilai signifikansi sebesar 0,185 yang artinya lebih besar dari tingkat signifikansi $0,05(0,185>0,05)$. Berdasarkan hasil penelitian ini, dapat disimpulkan bahwa kebijakan dividen tidak mampu memoderasi pengaruh kebijakan hutang terhadap nilai perusahaan pada perusahaan yang terdaftar di BEI. Ini sejalan dengan irrelevant theory yang diajukan oleh Modligani dan Miller bahwa kebijakan dividen tidak mempengaruhi nilai perusahaan atau biaya modal, tetapi nilai perusahaan tergantung pada kebijakan nilai investasi asetnya.

Hasil penelitian ini konsisten dengan hasil penelitian yang dilakukan oleh Nainggolan dan Listiadi (2014) menunjukkan bahwa kebijakan dividen tidak mampu memoderasi kebijakan hutang terhadap nilai perusahaan. Hal ini dikarenakan tinggi rendahnya dividen yang dibayarkan kepada pemegang saham, tidak berkaitan dengan tinggi rendahnya nilai perusahaan. Kebijakan hutang tidak dapat meningkatkan nilai perusahaan pada saat dividen 
yang dibayarkan perusahaan tinggi, begitu juga sebaliknya kebijakan hutang tidak dapat menurunkan nilai perusahaan pada saat dividen yang dibayarkan perusahaan rendah.

\section{SIMPULAN}

Hasil pengujian hipotesis pertama menunjukkan kepemilikan manajerial berpengaruh secara negatif terhadap nilai perusahaan. Hasil pengujian hipotesis kedua menunjukkan kepemilikan institusional berpengaruh terhadap nilai perusahaan. Hasil pengujian hipotesis ketiga menunjukkan kebijakan hutang tidak berpengaruh terhadap nilai perusahaan. Hasil pengujian hipotesis keempat menunjukkan bahwa kebijakan dividen mampu memoderasi pengaruh kepemilikan manajerial terhadap nilai perusahaan. Hasil pengujian hipotesis kelima menunjukkan bahwa kebijakan dividen mampu memoderasi pengaruh kepemilikan institusional terhadap nilai perusahaan. Hasil pengujian hipotesis keenam menunjukkan bahwa kebijakan dividen tidak mampu memoderasi pengaruh kebijakan hutang terhadap nilai perusahaan.

Untuk penelitian berikutnya disarankan agar memperpanjang periode penelitian. Penelitian selanjutnya disarankan untuk menguji variabel lain yang diduga berpengaruh terhadap nilai perusahaan. Pada penelitian ini, penulis hanya menggunakan satu proksi untuk masing masing variabel. Disarankan untuk penelitian selanjutnya memakai lebih banyak proksi atau mengganti proksi lain agar mendapatkan hasil penelitian yang lebih baik.

\section{REFERENSI}

Abdullah, N. M. H., Ahmad, Z. \& Roslan, S. (2012). The Influence of Ownership Structure on the Firms Dividend Policy Based Lintner Model. International Review of Business Research Papers, Vol. 8 No. 6, pp. 71-88.

Aditya, D. \& Supriyono, E. (2015). Pengaruh Profitabilitas dan Kepemilikan Institusional Terhadap Nilai Perusahaan Dengan Kebijakan Dividen Sebagai Variabel Intervening Pada Perusahaan Manufaktur yang Terdaftar di Bursa Efek Indoensia Periode 20102014. Jurnal Manajemen Bisnis. Vol. 6 No. 1, pp. 307-326.

Anita, A. \& Yulianto, A. (2016). Pengaruh Kepemilikan Manajerial dan Kebijakan Dividen Terhadap Nilai Perusahaan. Management Analysis Journal. Vol. 5 No. 1, pp. 17-23.

Atmaja, L.Y.S. (2009). Governance Mechanisms and Firm Value: The Impact of Ownership Concentration and Dividends. Corporate Governance: An International Review, Vol. 17. No. 6.

Bambang, R. (2011), Dasar-Dasar Pembelanjaan Perusahaan, 4th ed. Yogyakarta: YBPFE UGM.

Bernandhi, R. \& Muid, A. (2014). Pengaruh Kepemilikan Manajerial, Kepemilikan Institusional, Kebijakan Dividen, Leverage, dan Ukuran Perusahaan Terhadap Nilai Perusahaan. Diponegoro Journal of Accounting. Vol. 3 No. 1, pp. 1-14. 
Brigham, E. F. \& Houston, J. F. (2010). Dasar-Dasar Manajemen Keuangan. 10th ed. Salemba Empat. Jakarta.

Brigham, E. F. \& Houston, J. F. (2011). Dasar-Dasar Manajemen Keuangan Buku 2. 11th ed. Salemba Empat. Jakarta.

Budianto, W. \& Payamta. (2014). Pengaruh Kepemilikan Manajerial Terhadap Nilai Perusahaan Dengan Kebijakan Dividen Sebagai Variabel Moderasi. Assets: Jurnal Akuntansi dan Pendidikan. Vol. 3 No. 1, pp. 1-13.

Christiawan, Y.J. \& Tarigan, J. (2007). Kepemilikan Manajerial: Kebijakan Hutang, Kinerja dan Nilai Perusahaan. Jurnal Akuntansi dan Keuangan. Vol. 9 No. 1, pp. 1-8.

Damayanti, N.P.W.P. \& Suartana, I.W. (2014). Pengaruh Kepemilikan Manajerial dan Kepemilikan Institusional Pada Nilai Perusahaan. E-Jurnal Akuntansi Universitas Udayana. Vol. 9 No. 3, pp. 575-590.

Dewi, K.R.C. \& Sanica, I.G. (2017). Pengaruh kepemilikan institusional, kepemilikan manajerial, dan pengungkapan corporate social responsibility terhadap nilai perusahaan pada perusahaan manufaktur yang terdaftar di bursa efek indonesia. Jurnal Ilmiah Akuntansi Bisnis. Vol. 2 No. 1, pp. 1-25.

Febria, A. (2019). Efek Kiebijakan Dividen Sebagai Variabel Moderasi Pada Pengaruh Kebijakan Utang dan Profitabilitas Terhadap Nilai Perusahaan. Skripsi. Jurusan Manajemen Fakultas Ekonomi, Universitas Negeri Yogyakarta.

Ghozali, I. (2016). Aplikasi Analisis Multivariate Lanjutan Dengan Program SPSS. Semarang: Badan Penerbitan Universitas Diponegoro.

Hidayah, N. (2015). Pengaruh Investment Opportunity Set (IOS) dan Kepemilikan Manajerial Terhadap Nilai Perusahaan Pada Perusahaan Property dan Real Estat di Bursa Efek Indonesia. Jurnal Akuntansi. Vol. 19 No. 3, pp. 420-432.

Husnan, S. (2010). Manajemen Keuangan Teori dan Penerapan (Keputusan Jangka Panjang). 4th ed. BPFE Yogyakarta: Yogyakarta.

Itturiaga, F.J.L. \& Crisostomo, V.L. (2010). Do Leverage, Dividend Payout, and Ownership Concentration Influence Firms' Value Creation? An Analysis of Brazilian Firms", Emerging Markets Finance \& Trade. Vol. 46 No. 3, pp. 80-94.

Jensen, M.C. (1986). Agency Costs and Free Cash Flow, Corporate Finance and Takeovers. American Economic Review. Vol. 76 No. 2, pp. 323-329.

Jensen, M.C. \& Meckling, W.H. (1976). Theory of The Firm: Managerial Behavior, Agency Costs And Ownership Structure. Journal of Financial Economics. Vol. 3, pp. 305-360.

Kasmir. (2012). Analisis Laporan Keuangan. Jakarta: Raja Grafindo Persada.

Kusumaningrum, D.A.R. \& Rahardjo, S.N. (2013), "Pengaruh Keputusan Investasi, Keputusan Pendanaan, Kebijakan Dividen, Kepemilikan Manajerial, dan Kepemilikan Institusional Terhadap Nilai Perusahaan (Studi Empiris Pada Perusahaan yang 
Terdaftar di Bursa Efek Indonesia Tahun 2011-2012). Diponegoro Journal of Accounting. Vol. 2 No. 4, pp. 1-10.

Lestari. (2017). Pengaruh Kepemilikan Institusional dan Struktur Modal Terhadap Nilai Perusahaan. Jurnal Riset Manajemen Dan Bisnis (JRMB). Vol. 2 No. 1, pp. 293-306.

Mardiyati, U., Ahmad, G.N. \& Putri, R. (2012). Pengaruh Kebijakan Dividen, Kebijakan Hutang dan Profitabilitas Terhadap Nilai Perusahaan Manufaktur yang Terdaftar di Bursa Efek Indonesia (BEI) Periode 2005-2010. Jurnal Riset Manajemen Sains Indonesia (JRMSI),.Vol. 3 No. 1, pp. 1-17.

Martono \& Harjitno, A. (2010). Manajemen Keuangan. 3rd ed. Yogyakarta: Ekonisia.

Nainggolan, S.D.A. \& Listiadi, A. (2014). Pengaruh Kebijakan Hutang Terhadap Nilai Perusahaan Dengan Kebijakan Dividen Sebagai Variabel Moderasi. Jurnal Ilmu Manajemen. Vol. 2 No. 3, pp. 868-879.

Normayanti. (2017). Pengaruh Kebijakan Hutang, Kebijakan Dividend an Profitabilitas Terhadap Nilai Perusahaan. EJournal Administrasi Bisnis. Vol. 5 No. 2, pp. 376-389.

Nuraina, E. (2012). Pengaruh Kepemilikan Institusional dan Ukuran Perusahaan Terhadap Kebijakan Hutang dan Nilai Perusahaan. AKRUAL (Jurnal Akuntansi). Vol. 4 No. 1, pp. 51-70.

Olweny, T. (2012). Dividend Announcement and Firm Value: A Test of Semi Strong Form of Efficiency at the Nairobi Stock Exchange. Asian Social Science. Vol. 8 No. 1, pp. $161-175$.

Osman, D. \& Mohammed, E. (2010). Dividend policy in Saudi Arabia. The International Journal of Business and Finance Research. Vol. 4 No. 1, pp. 99-113.

Pertiwi, P.J., Tommy, P. \& Tumiwa, J.R. (2016). Pengaruh Kebijakan Hutang, Keputusan Investasi, dan Profitabilitas Terhadap Nilai Perusahaan Food And Beverages Yang Terdaftar di Bursa Efek Indonesia. Jurnal EMBA: Jurnal Riset Ekonomi, Manajemen, Bisnis, dan Akuntansi. Vol. 4 No. 1, pp. 1369-1380.

Pracihara, S.M. (2016). Pengaruh Kebijakan Hutang, Kepemilikan Manajerial, Kebijakan Dividen, dan Ukuran Perusahaan Terhadap Nilai Perusahaan (Studi pada Sektor Pertambangan yang Terdaftar di BEI Periode 2011-2014). Jurnal Ilmu Manajemen (JIM). Vol. 4 No. 2, pp. 1-10.

Pratiwi, M.I., Kristianti, F.T. \& Mahardika, D.P.K. (2016). Pengaruh Kepemilikan Manajerial, Kepemilikan Institusional, dan Leverage Terhadap Nilai Perusahaan. E-Proceeding of Management. Vol. 3, pp. 3191-3197.

Pratiwi, N.P.D. \& Mertha, M. (2017). Pengaruh Kebijakan Hutang dan Profitabilitas Pada Nilai Perusahaan Dengan Kebijakan Dividen Sebagai Variabel Pemoderasi. E-Jurnal Akuntansi Universitas Udayana. Vol. 20 No. 2, pp. 1446-1475.

Putri, A.R. (2017). Pengaruh Kebijakan Hutang, Profitabilitas, Likuiditas dan Kesempatan Investasi Terhadap Kebijakan Dividen. Jurnal Ilmu Dan Riset Akuntansi,.Vol. 6 No. 6 , pp. $1-15$. 
Rahma, A. (2014). Pengaruh Kepemilikan Manajerial, Kepemilikan Institusional, dan Ukuran Perusahaan Terhadap Keputusan Pendanaan dan Nilai Perusahaan (Studi Kasus Pada Perusahaan Manufaktur yang Terdaftar di Bursa Efek Indonesia Priode 2009-2012). Jurnal Bisnis Strategi. Vol. 23 No. 2, pp. 45-69.

Ramadhan, G.F., Husnatarina, F. \& Angela, L.M. (2018). Pengaruh Kebijakan Hutang dan Kebijakan Dividen Terhadap Nilai Perusahaan Kelompok LQ 45 yang Terdaftar di Bursa Efek Indonesia Tahun 2012-2016. Jurnal RAK (Riset Akuntansi Keuangan). Vol. 3 No. 1.

Sartono, R.A. (2010). Manajemen Keuangan Teori Dan Aplikasi. 4th ed. Yogyakarta: BPFE.

Septriani, D. (2017). Pengaruh Kebijakan Dividen dan Kebijakan Hutang Terhadap Nilai Perusahaan (Studi Empiris Pada Perusahaan LQ45 di BEI Periode 2012-2015). Journal of Applied Business and Economics. Vol. 3 No. 3, pp. 183-195.

Sofyaningsih, S. \& Hardiningsih, P. (2011). Struktur Kepemilikan, Kebijakan Dividen, Kebijakan Utang dan Nilai Perusahaan”, Dinamika Keuangan Dan Perbankan, Vol. 3 No. 1, pp. 69-87.

Sugiarto, M. (2011). Pengaruh Struktur Kepemilikan dan Kebijakan Dividen Terhadap Nilai Perusahaan Dengan Kebijakan Hutang Sebagai Intervening. Jurnal Akuntansi Kontemporer. Vol. 3 No. I, pp. 1-25.

Sukirni, D. (2012). Kepemilikan Manajerial, Kepemilikan Institusioanl, Kebijakan Deviden dan Kebijakan Hutang Analisis Terhadap Nilai Perusahaan. Accounting Analysis Journal, Vol. 1 No. 2, pp. 1-12.

Sulong, Z. \& Nor, F.M. (2010). Corporate Governance Mechanisms and Firm Valuation in Malaysian Listed Firms : A Panel Data Analysis. Journal of Modern Accounting and Auditing. Vol. 6 No. 1, pp. 1-18.

Suta, I.W.P., Agustina, P.A.A. \& Sugiarta, I.N. (2016). Pengaruh Kebijakan Utang Pada Nilai Perusahaan Dengan Kepemilikan Institusional Sebagai Variabel Moderasi (Studi pada Perusahaan Manufaktur di Bursa Efek Indonesia). Jurnal Bisnis dan Kewirausahaan, Vol. 12 No. 3, pp. 173-185.

Tambalean, F.A.K., Manossoh, H. \& Runtu, T. (2018). Pengaruh Kepemilikan Manajerial dan Kepemilikan Institusional Terhadap Nilai Perusahaan Pada Perusahaan Sektor Industri Barang Konsumsi di BEI. Jurnal Riset Akuntansi Going Concern. Vol. 13 No. 4, pp. 465-473.

Warapsari, A.A.A.U. \& Suaryana, I.G.N.A. (2016). Pengaruh Kepemilikan Manajerial dan Institusional Terhadap Nilai Perusahaan Dengan Kebijakan Utang Sebagai Variabel Intervening. E-Jurnal Akuntansi Universitas Udayana. Vol. 16 No. 3, pp. 2288-2315.

Wulandari, E.W. (2016). Pengaruh Kepemilikan Institusional dan Kepemilikan Manajerial Terhadap Manajemen Laba Pada Perusahaan Manufaktur yang Terdaftar di Bei 20122015. Jurnal Akuntansi AKUNESA. Vol. 5 No. 1, pp. 1-15. 
Zahro, H. (2018). Pengaruh Kepemilikan Institusional Terhadap Nilai Perusahaan dan Kinerja Keuangan Sebagai Variabel Intervening. Jurnal Akuntansi AKUNESA. Vol. 6 No. 3. 